\title{
Front Matter: Volume 9470
}

, "Front Matter: Volume 9470," Proc. SPIE 9470, Display Technologies and Applications for Defense, Security, and Avionics IX; and Head- and HelmetMounted Displays XX, 947001 (22 June 2015); doi: 10.1117/12.2202192

SPIE. Event: SPIE Defense + Security, 2015, Baltimore, MD, United States 


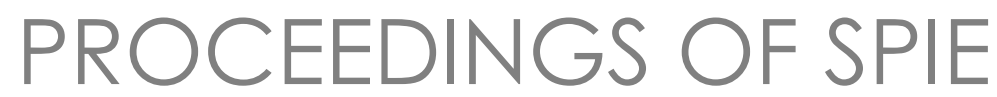

\title{
Display Technologies and Applications for Defense, Security, and Avionics IX; and Head-and Helmet-Mounted Displays XX
}

\author{
Daniel D. Desjardins \\ Peter L. Marasco \\ Kalluri R. Sarma \\ Paul R. Havig \\ Michael P. Browne \\ James E. Melzer \\ Editors
}

21-23 April 2015

Baltimore, Maryland, United States

Sponsored and Published by

SPIE

Volume 9470 
The papers included in this volume were part of the technical conference cited on the cover and title page. Papers were selected and subject to review by the editors and conference program committee. Some conference presentations may not be available for publication. The papers published in these proceedings reflect the work and thoughts of the authors and are published herein as submitted. The publisher is not responsible for the validity of the information or for any outcomes resulting from reliance thereon.

Please use the following format to cite material from this book:

Author(s), "Title of Paper," in Display Technologies and Applications for Defense, Security, and Avionics IX; and Head-and Helmet-Mounted Displays XX, edited by Daniel D. Desjardins,

Kalluri R. Sarma, Peter L. Marasco, Paul R. Havig, Michael P. Browne, James E. Melzer, Proceedings of SPIE Vol. 9470 (SPIE, Bellingham, WA, 2015) Article CID Number.

ISSN: 0277-786X

ISBN: 9781628415865

Published by

SPIE

P.O. Box 10, Bellingham, Washington 98227-0010 USA

Telephone +1 3606763290 (Pacific Time) · Fax +1 3606471445

SPIE.org

Copyright (c) 2015, Society of Photo-Optical Instrumentation Engineers.

Copying of material in this book for internal or personal use, or for the internal or personal use of specific clients, beyond the fair use provisions granted by the U.S. Copyright Law is authorized by SPIE subject to payment of copying fees. The Transactional Reporting Service base fee for this volume is $\$ 18.00$ per article (or portion thereof), which should be paid directly to the Copyright Clearance Center (CCC), 222 Rosewood Drive, Danvers, MA 01923. Payment may also be made electronically through CCC Online at copyright.com. Other copying for republication, resale, advertising or promotion, or any form of systematic or multiple reproduction of any material in this book is prohibited except with permission in writing from the publisher. The CCC fee code is 0277-786X/15/\$18.00.

Printed in the United States of America.

Publication of record for individual papers is online in the SPIE Digital Library.

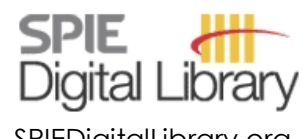

SPIEDigitalLibrary.org

Paper Numbering: Proceedings of SPIE follow an e-First publication model, with papers published first online and then in print. Papers are published as they are submitted and meet publication criteria. A unique citation identifier (CID) number is assigned to each article at the time of the first publication. Utilization of CIDs allows articles to be fully citable as soon as they are published online, and connects the same identifier to all online, print, and electronic versions of the publication. SPIE uses a six-digit CID article numbering system in which:

- The first four digits correspond to the SPIE volume number.

- The last two digits indicate publication order within the volume using a Base 36 numbering system employing both numerals and letters. These two-number sets start with 00, 01, 02, 03, 04, $05,06,07,08,09,0 A, 0 B \ldots$. OZ, followed by 10-1Z, 20-2Z, etc.

The CID Number appears on each page of the manuscript. The complete citation is used on the first page, and an abbreviated version on subsequent pages. 


\title{
Contents
}

\author{
vii Authors \\ ix Conference Committee \\ xiii Introduction to Display Technologies and Applications for Defense, Security, and \\ Avionics IX
}

\section{Part A Display Technologies and Applications for Defense, Security, and Avionics IX}

SESSION 1 HEAD AND HELMET MOUNTED DISPLAYS AND DISPLAY TECHNOLOGIES AND APPLICATIONS FOR DEFENSE, SECURITY, AND AVIONICS: JOINT SESSION WITH CONFERENCES 9470A AND 9470B

947003 The impact of coloured symbology on cockpit eyes-out display effectiveness: a survey of key parameters [9470-35]

947004 Augmented reality technology for day/night situational awareness for the dismounted Soldier [9470-2]

\section{SESSION 2 HEAD-MOUNTED AND BODY-WORN DISPLAYS}

$947007 \quad$ Keeping display visibility in outdoor environment [9470-5]

\section{SESSION $3 \quad$ STEREOSCOPIC 3D DISPLAYS}

947009 3D display considerations for rugged airborne environments [9470-8]

9470 0A A guide for human factors research with stereoscopic 3D displays [9470-9]

\section{SESSION 4 IMMERSIVE ENVIRONMENTS AND AUGMENTED REALITY}

$9470 \mathrm{OB} \quad$ Exploring immersive environments to aid urban intelligence, surveillance and reconnaissance operations [9470-10]

9470 OC Augmented reality enabling intelligence exploitation at the edge [9470-1 1] 
9470 OD A virtual pixel software and hardware technology to increase projector resolution [9470-12]

$9470 \mathrm{OE} \quad$ A virtual pixel technology to enhance the resolution of monitors and for other purposes [9470-13]

\section{SESSION 6 DISPLAY PERFORMANCE RESEARCH AND ADVANCES}

9470 OF Review of the evolution of display technologies for next-generation aircraft (Invited Paper) [9470-14]

9470 OG A neuroergonomic quasi-experiment: predictors of situation awareness and display usability while performing complex tasks [9470-15]

$9470 \mathrm{OH} \quad$ A practical definition of eye-limited display system resolution [9470-16]

9470 0l Just noticeable color difference: implications for display systems [9470-17]

\section{SESSION 7 FLEXIBLE DISPLAYS}

9470 0J Recent progress in OLED and flexible displays and their potential for application to aerospace and military display systems (Invited Paper) [9470-18]

\section{SESSION 8 CORNUCOPIA}

9470 OL Analog video to ARINC 818 [9470-20]

9470 OM Electro-textile garments for power and data distribution [9470-21]

\section{Part B Head- and Helmet-Mounted Displays XXL Design and Applications}

SESSION 9 HEAD AND HELMET MOUNTED DISPLAYS: A RETROSPECTIVE

9470 OT A history of helmet mounted displays (Invited Paper) [9470-25]

$9470 \mathrm{OU} \quad$ The impact of human factors, crashworthiness and optical performance design requirements on helmet-mounted display development from the 1970s to the present (Invited Paper) [9470-26]

9470 OV In the blink of an eye: head mounted displays development within BAE Systems (Invited Paper) [9470-27]

9470 OW A review of head-worn display research at NASA Langley Research Center (Invited Paper) [9470-28] 
9470 OX Flight test of a head-worn display as an equivalent-HUD for terminal operations [9470-29]

9470 OY Dynamic registration of an optical see-through HMD into a wide field-of-view rotorcraft flight simulation environment [9470-30]

$9470 \mathrm{OZ} \quad$ Visibility of monocular symbology in transparent head-mounted display applications [9470-31]

947010 Visual fatigue induced by optical misalignment in binocular devices: application to night vision binocular devices [9470-32]

\section{SESSION 11 ENABLING TECHNOLOGIES}

947011 Enhancing head and helmet-mounted displays using a virtual pixel technology [9470-33]

POSTER SESSION

947013 Development of a helmet/helmet-display-unit alignment tool (HAT) for the Apache helmet and display unit [9470-36] 
Proc. of SPIE Vol. $9470947001-6$

Downloaded From: https://www.spiedigitallibrary.org/conference-proceedings-of-spie on 25 Apr 2023 Terms of Use: https://www.spiedigitallibrary.org/terms-of-use 


\section{Authors}

Numbers in the index correspond to the last two digits of the six-digit citation identifier (CID) article numbering system used in Proceedings of SPIE. The first four digits reflect the volume number. Base 36 numbering is employed for the last two digits and indicates the order of articles within the volume. Numbers start with 00, 01, 02, 03, 04, 05, 06, 07, 08, 09, 0A, 0B...0Z, followed by 10-1Z, 20-2Z, etc.

Adkins, Donald, OB

Arthur, Jarvis (Trey) J., III, OW, OX

Bailey, Randall E., OW, OX

Barnidge, Tracy J., 09, OF

Battista, Josephine, 10

Bennett, Matthew, 04

Booms, Shawn, 13

Bowman, Elizabeth K., OC

Cameron, Alex, OV

Christensen, James C., OG

Cook, James, 04

Desjardins, Daniel D., Ol

Donval, Ariela, 07

Dotan, Ido, 07

Estes, Victor, 13

Fares, Maha, 03

Foote, Bob, OT

Gans, Eric, 04

Gardner, Patrick, Ol

Gaska, J., OH, OZ

Gavrilescu, Maria, 10

Gibbs, Peter, 10

Gross, Noam, 07

Grunwald, Paul, OL

Hadley, S., $\mathrm{OZ}$

Hajek, Manfred, OY

Harbour, Steven D., OG

Harding, Thomas H., OU, 13

Havig, Paul R., OA

Houston, Vincent, OW

Ibbotson, Michael R., 10

Jones, Denise R., OW

Jordan, Derek R., 03

Kading, Benjamin, OD, OE, 11

Kase, Sue E., OC

Lampke, Sarah, OB

Lipman, Ofir, 07

Lloyd, Charles J., $\mathrm{OH}$

Martin, John S., OU, 13

Mclntire, John P., OA

McLean, William E., 0U, 13

Melzer, James, OT

Menozzi, Alberico, 04

MtCastle, Timothy, OB

Nicholas, S. N., OX

Oron, Moshe, 07

Partouche, Eran, 07

Patterson, R., $\mathrm{OZ}$

Patton, Debra, 0C
Pierce, B., OZ

Pinkus, Alan R., OA

Prinzel, Lawrence J., III, OW, OX

Rash, Clarence E., OU

Roberts, David, 04

Roll, Jason, OB

Roy, Heather, OC

Sarma, Kalluri, OJ

Shelton, Kevin J., OW, OX

Sherrill, Todd, 04

Slade, Jeremiah R., OM

Statz, Jonathan, 13

Straub, Jeremy, OD, OE, 11

Tchon, Joseph L., 09, OF

Towles, Herman, 04

Venero, Peter, OB

Viertler, Franz, OY

Williams, L., $\mathrm{OH}$

Williams, Steven P., OW, OX

Winterbottom, M., $\mathrm{OH}, \mathrm{OZ}$

Winterhalter, Carole, $\mathrm{OM}$ 
Proc. of SPIE Vol. $9470947001-8$

Downloaded From: https://www.spiedigitallibrary.org/conference-proceedings-of-spie on 25 Apr 2023 Terms of Use: https://www.spiedigitallibrary.org/terms-of-use 


\section{Conference Committee}

Symposium Chair

Nils R. Sandell Jr., Strategic Technology Office, DARPA

(United States)

Symposium Co-chair

David A. Logan, BAE Systems (United States)

\section{Part A Display Technologies and Applications for Defense, Security, and Avionics IX}

Conference Chairs

Daniel D. Desjardins, Consultant (United States)

Kalluri R. Sarma, Honeywell Technology (United States)

Conference Program Committee

Masoud Ali, Barco, Inc. (United States)

Hari M. Atkuri, BEAM Engineering for Advanced Measurements Company (United States)

Philip J. Bos, Kent State University (United States)

Alexander A. Cameron, BAE Systems (United Kingdom)

Reginald Daniels, Air Force Research Laboratory (United States)

Timothy J. Edwards, Kopin Corporation (United States)

Jean-Michel Francois, Thales Avionics S.A. (France)

Gary W. Jones, Nano Quantum Sciences, Inc. (United States)

Charles J. Lloyd, Visual Performance, LLC (United States)

John P. McIntire, Air Force Research Laboratory (United States)

Raymond Schulze, U.S. Army CERDEC CP\&I Directorate

(United States)

Joe Tchon, Rockwell Collins, Inc. (United States)

Paul L. Wisely, Holoeye Systems (United States)

Session Chairs

Head and Helmet Mounted Displays and Display Technologies and Applications for Defense, Security, and Avionics: Joint Session with Conferences $9470 \mathrm{~A}$ and $9470 \mathrm{~B}$

Peter L. Marasco, Air Force Research Laboratory (United States) 
Head-Mounted and Body-Worn Displays

Kalluri R. Sarma, Honeywell Technology (United States)

Stereoscopic 3D Displays

Reginald Daniels, Air Force Research Laboratory (United States)

Immersive Environments and Augmented Reality

Jean-Michel Francois, Thales Avionics S.A. (France)

Increased Resolution Via Virtual Pixel

Joseph L. Tchon, Rockwell Collins, Inc. (United States)

Display Performance Research and Advances

Gary W. Jones, NanoQuantum Sciences, Inc. (United States)

Flexible Displays

Paul L. Wisely, HOLEEYE Systems Inc (United States)

Cornucopia

Daniel D. Desjardins, Consultant (United States)

\section{Part B Head-and Helmet-Mounted Displays XX: Design and Applications}

Conference Chairs

Peter L. Marasco, Air Force Research Laboratory (United States)

Paul R. Havig, Air Force Research Laboratory (United States)

Michael P. Browne, SA Photonics (United States)

James E. Melzer, Rockwell Collins Optronics (United States)

Conference Program Committee

Randall E. Bailey, NASA Langley Research Center (United States)

Sion Jennings, National Research Council Canada (Canada)

Session Chairs

Head and Helmet Mounted Displays: A Retrospective

Michael P. Browne, SA Photonics (United States)

Testing and Human Factors of HMDs

James E. Melzer, Rockwell Collins Optronics (United States) 
Head and Helmet Mounted Displays and Display Technologies and Applications for Defense, Security, and Avionics: Joint Session with Conferences 9470A and 9470B

Peter L. Marasco, Air Force Research Laboratory (United States)

Proc. of SPIE Vol. $9470947001-11$

Downloaded From: https://www.spiedigitallibrary.org/conference-proceedings-of-spie on 25 Apr 2023 Terms of Use: https://www.spiedigitallibrary.org/terms-of-use 
Proc. of SPIE Vol. $9470947001-12$

Downloaded From: https://www.spiedigitallibrary.org/conference-proceedings-of-spie on 25 Apr 2023 Terms of Use: https://www.spiedigitallibrary.org/terms-of-use 


\section{Introduction}

The Display Technologies and Applications for Security, Defense \& Avionics IX Conference served, per previous such conferences, as a forum for display related papers regarding a wide range of civil, Department of Defense, and Homeland Security systems. Proceedings Volume 9470A includes 16 papers presented across eight sessions, to include: Head-Mounted and Body-Worn Displays, Stereoscopic 3D Displays, Immersive Environments and Augmented Reality, Increased Resolution Via Virtual Pixels, Display Performance Research and Advances, Flexible Displays, Cornucopia (for disparate display subject areas), and a joint session with our sister conference (9470B) on Head- and Helmet-Mounted Displays.

The above-mentioned Joint Session was in fact our first session, held on 22 April, as a bridge between the DS122 program and our own. It began with a paper from BAE presenting a survey of key parameters relating to the impact of colored symbology for head-up displays. It was followed by a presentation from Applied Research describing recent advances in soldier augmented reality (AR) technology. This paper provided details regarding current research and development efforts toward helmet-based and handheld AR systems and discussed key metrics used to assess an effective AR experience, including those related to pose estimation, through-sight display, and computer processing. Due to travel problems affecting Great River Technology, theirs was the final paper in this session, describing the combining of multiple-channel RS-170 and multiplexing the various channels into a single fiber optic cable. The paper also discussed alternative architectures and how ARINC 818 can be utilized with aging aircraft legacy systems. It is to be noted this joint session drew an audience of some 70 persons, a better than average attendance for either DS122 or DS123 alone, suggesting the utility of continuing further such sessions in 2016.

Session 2 on 23 April opened the independent part of our program, and continued the theme of Head-Mounted Displays and now adding Body-Worn Displays. The first paper was an invited paper by keynote speaker Dr. Hong Hua, of the University of Arizona College of Optical Sciences, who reviewed past and current technological advancements in head-mounted displays, with emphasis on optical see-through HMDs for applications to augmented reality. Dr. Hua's presentation gave examples of HMD systems developed by UAC's 3-D Visualization and Imaging Systems Laboratory based on emerging freeform optics, and discussed key technical challenges and opportunities for future developments. A second paper by KiloLambda Technologies spoke about the development of a solid-state, self-adaptive Dynamic Sunlight Filter (DSF) as a passive means to variably attenuate visible light according to intensity for seethrough HMDs. The author spoke about DSF functionality, to include new capabilities adapted mostly for avionic, but also non-avionic applications. There 
were some 90 attendees during this second session, thanks to the reputation of our key-note speaker and SPIE's incentive to attract such speakers, and we look forward to leveraging this innovative program again next year.

Session 3, treating the subject of Stereoscopic 3D Displays, introduced a paper by Rockwell Collins on the development of the Remote Vision System (RVS) that supports aerial refueling operations for Boeing's next generation aerial refueling tanker, the KC-46. This presentation reviewed the design considerations, trade-offs and other factors related to the selection and ruggedization of the 3D display technology for this military platform. The paper was followed by another stereoscopic 3D (S3D) paper from the US Air Force Research Lab that provided some common methods, techniques, information, concepts, and relevant citations for those conducting human factors-related research with S3D displays. The paper suggested methods for calculating binocular disparities, provided typical values for inter-pupillary distances, discussed the pros and cons of common stereovision clinical tests, and discussed the phenomena and prevalence of stereoanomalous, pseudo-stereoanomalous, stereo-deficient, and stereoblind viewers, covering the implications of these issues for the human factors study of S3D displays throughout.

Another paper from the US Air Force Research Lab opened Session 4 regarding Immersive Environments and Augmented Reality. This paper focused on the use of immersive environments as a potential solution to the occlusion of sensor data regarding Intelligence, surveillance, and reconnaissance (ISR) in urban areas. The author outlined methods and results of an experiment to investigate the impact that different fields of view (FOV) and different control devices on operator actions, to include navigating the environment, selecting sensors in the environment, and manipulating those selected sensors. This paper was followed by one from the US Army Research Lab on augmented reality as an enabler to intelligence exploitation. Recognizing the gap in real-time processing of big data social media streams, USARL has developed a big data processing pipeline that ingests, monitors, and performs a variety of analytics including noise reduction, pattern identification, and trend and event detection for a given area of operations. The paper reported preliminary observations testing Glass (an alerting framework and augmented reality device) with the ODROID platform (a powerful wearable computing device) simulating edge Soldier participation in the intelligence process during disconnected deployment conditions.

Session 5 on Increased Resolution via Virtual Pixel techniques witnessed two papers, both from the University of North Dakota. The first of the two papers proposed an approach for increasing projector resolution, while minimizing projector size and weight. The proposed technology introduces a mechanism to combine the output of multiple LCD panels and alters of the configuration of the pixels faster than the desired frame rate, allowing aggregation both temporally and spatially. The approach visually combines the coloration of adjacent pixels to create an approximation of what would be projected by a higher resolution 
screen. The paper described the approach in detail, and concluded by describing the prospective benefits. The second paper from UND, proposed a pixel combination function to average the output of multiple pixels to create a greater number of different virtual pixels, as compared to the number of emitting LCDs (or similar). The co-author described a display technique based on reversing the principles typically used in computer image super-resolution, based on a combination of software and hardware components. The presentation provided an overview of the proposed technology, discussed its application to monitors and possible extension to other applications, and concluded with a discussion of prospective next steps to its development.

Session 6 followed the lunch break with four papers presented on the theme of Display Performance Research and Advances. The first paper, an invited paper and the second by Rockwell Collins, reviewed the evolution of display technologies for next generation aircraft, with a particular focus on the KC-46 aerial tanker. The author discussed progress in display operating modes, backlighting, packaging and ruggedization, along with display certification considerations across military and civilian platforms. The second paper from US Air Force Aeronautical Systems Center spoke about quantitative research that examined basic neurocognitive factors, including visual abilities and working memory, in order to identify their specific contributions to the formation of cognitive situation awareness. The study assessed the predictive value of visual attentiveness $\left(V_{a}\right)$, perceptiveness $\left(V_{p}\right)$, and spatial working memory $\left(V_{\text {swm }}\right)$ as predictors of situation awareness during 24 flight trials under varying task difficulty using repeated-measures comparisons. The author claimed the results made a significant addition to the existing theoretical model of situation awareness by showing $v_{p}$ to have the strongest relationship of the three neurocognitive factors, although $V_{a}$ had the strongest correlation with situation awareness during high task difficulty, and $V_{\text {swm }}$ had the strongest correlation during low task difficulty. The author pointed up practical implications for improved cockpit design and enhanced training by targeting attentional, perceptual, and visuospatial working memory skill learning. A third paper from Visual Performance summarized the results of published evaluations and experiments conducted by the author relating to resolution requirements. The results of several evaluations employing sufficient anti-aliasing indicate a pixel pitch of 0.5 to 0.7 arcmin will produce $90 \%$ of peak performance for observers with $20 / 20$ or better visual acuity for a variety of visual tasks. However, if insufficient anti-aliasing is employed, spurious results can indicate that a finer pixel pitch is required to avoid visible sampling artifacts. The final paper of this session came from the University of Western Carolina's Center for Rapid Product Realization, wherein the author related preliminary results of a laboratory study intended to characterize just noticeable differences (JND) in luminance at fixed hue and saturation for the three color primaries of a given display under test. Test results appeared to indicate that only under conditions of some threshold maximum luminance do a specified number of gray levels give the viewer the possibility of a JND for each of the advertised levels. The results further appeared to indicate that luminance level decrements necessary 
to achieve just noticeable differences are not only non-linear but differ for red, green, and blue, suggesting a requirement for separate gamma algorithms that vary with dimming.

Session 7, due to cancellations, entailed a singular invited paper from Honeywell. As the session's theme was Flexible Displays, this paper reviewed the impact of the recent advances in LTPS and AOS Thin Film Transistors, Red, Green, Blue and White Organic Light Emitting Diodes (OLED) with color filter pixel architectures, encapsulation and system level engineering, on the success of OLEDs in consumer electronic devices. The author also discussed the potential of these advances in addressing the requirements of OLEDs and flexible displays for military and avionic applications.

Session 8, "Cornucopia," unfortunately suffered from transfers, cancellations and no-shows to allow but one paper. That paper was from Infoscitex addressing the topic of electro-textile garments. The author outlined the development of a number of critical technologies needed to integrate large-scale, cross-seam, electrical functionality into a variety of textile systems, focusing specifically on a product called Selectively Enabled Wiring in Textiles (SEWit). SEWit was described as a technology that can be created in a variety of textile products including garments, plate carriers, backpacks and tents, without the need for conventional wires or cables, thus eliminating the shortcomings associated with previous etextile and wearable-electronic products. The technology allows textile products that do not simply support or accommodate a network but are the network.

Best Paper: We would like to extend our sincere congratulations to Dr. Hang Hua of the College of Optical Sciences, University of Arizona, winner of this year's Best Paper award: "Review and current status of head-mounted display technologies". Please join us in congratulating Dr. Hua on this fine achievement!

As a final note, we wish to thank all who attended this year's conference. We enjoyed seeing and speaking with you, and for those who attended as authors, listening to and learning from your papers. In preparing for next year, we will continue to solicit greater participation from the military community, expand our base within the displays industry and recruit more papers from university authors. Please look for the Call which shall be issued in late June and be sure to alert your colleagues and co-workers about submitting their abstracts early. Thank you, and we look forward to seeing you again in 2016 !

Daniel D. Desjardins Kalluri R. Sarma 